\title{
PERBEDAAN KADAR PLASMINOGEN ACTIVATOR INHIBITOR-1 CAIRAN PERITONEUM TIKUS WISTAR ANTARA YANG DIBERI VITAMIN E TOPIKAL ATAU KETOROLAK INTRAMUSKULAR ATAU SIMVASTATIN ORAL ATAU KOMBINASI KETIGANYA PADA TIKUS WISTAR YANG DILAKUKAN ABRASI ILEUM
}

\author{
Kadek Deddy Ariyanta', Dikki Drajat Kusmayadi ${ }^{2}$, Rizki Diposarosa² \\ ${ }^{1}$ Program Pendidikan Dokter Spesialis Ilmu Bedah Anak, Fakultas Kedokteran Universitas Padjadjaran, Rumah \\ Sakit Dr. Hasan Sadikin, Bandung. Korespondensi: deddyariyanta@yahoo.com \\ ${ }^{2}$ Departemen Ilmu Bedah Anak, Fakultas Kedokteran Universitas Padjadjaran, Rumah Sakit Dr. Hasan Sadikin, \\ Bandung.
}

\begin{abstract}
ABSTRAK
Tujuan: untuk membuktikan adanya perbedaan kadar plasminogen activator inhibitor-1 (PAI-1) cairan peritoneum tikus Wistar antara yang tidak diberi obat, diberi obat tunggal vitamin E topikal atau ketorolak intramuskular atau simvastatin oral dengan yang diberi obat kombinasi ketiganya pada tikus Wistar yang dilakukan abrasi ileum. Metode: penelitian eksperimental laboratorik, menggunakan tikus Wistar jantan. Tiga puluh ekor tikus Wistar dilakukan abrasi ileum dan dibagi 5 kelompok: kontrol (K); perlakuan 1, diberi vitamin E topikal (P1); perlakuan 2, diberi ketorolak intramuskular (P2); perlakuan 3, diberi simvastatin oral (P3); dan perlakuan 4, diberi kombinasi vitamin $\mathrm{E}$ topikal, ketorolak intramuskular, dan simvastatin oral (P4). Cairan peritoneum diambil 7 hari kemudian untuk mendapatkan kadar PAI-1 cairan intraperitoneum. Uji beda kadar PAI-1 cairan peritoneum dengan uji one way ANOVA dan Dunett's T3. Hasil: kadar PAI-1 cairan peritoneum tikus Wistar yang dilakukan abrasi ileum antara kelompok kontrol dengan kelompok kombinasi $(\mathrm{p}=0,046)$, kelompok vitamin $\mathrm{E}$ dengan kombinasi $(\mathrm{p}=0,000)$, kelompok ketorolak dengan kombinasi $(\mathrm{p}=0,000)$, dan kelompok simvastatin dengan kombinasi $(\mathrm{p}=0,002)$. Simpulan: kadar PAI-1 cairan peritoneum lebih rendah secara bermakna pada kelompok yang diberi perlakuan kombinasi dibandingkan dengan pemberian obat tunggal dan yang tidak diberi.
\end{abstract}

Kata kunci: fibrinolisis, adhesi, plasminogen activator inhibitor-1, vitamin E, ketorolak, simvastatin.

\section{THE DIFFERENCES OF PLASMINOGEN ACTIVATOR INHIBITOR-1 LEVEL IN PERITONEUM FLUID AMONG RATS GIVEN TOPICAL VITAMIN E OR INTRAMUSCULAR KETOROLAC OR ORAL SIMVASTATIN WITH RATS GIVEN COMBINATION OF THOSE THREE DRUGS IN RATS PERFORMED ILLEAL ABRASIONS}

\author{
Kadek Deddy Ariyanta ${ }^{1}$, Dikki Drajat Kusmayadi², Rizki Diposarosa² \\ ${ }^{1}$ Child Surgery Training Programme, Faculty of Medicine, Padjadjaran University, Dr. Hasan Sadikin Hospital, \\ Bandung. \\ ${ }^{2}$ Child Surgery Department, Faculty of Medicine, Padjadjaran University, Dr. Hasan Sadikin Hospital, Bandung.
}

\begin{abstract}
Objective: to determine difference level of plasminogen activator inhibitor-1 (PAI-1) in peritoneal fluid between control group, single administration of the drug group, topical vitamin E, intramuscular ketorolac, oral simvastatin, and combination effects of all three drug. Methods: this was an experimental study. Thirty rats performed ileal abrasions, then assigned to five groups: control $(\mathrm{K})$;
\end{abstract}


group 1, given topical vitamin E (P1); group 2, given intramuscular ketorolac (P2); group 3, given oral simvastatin (P3); and group 4 combination of vitamin E, ketorolac, and simvastatin (P4). The measurement of PAI-1 in peritoneal fluid was performed after 7th days. One way ANOVA and Dunett's T3 was used to analyzed level of PAI-1 degree differences. Results: there was significant differences level of PAI-1 peritoneal fluid between control group and combination group $(\mathrm{p}=0.046)$, vitamin $\mathrm{E}$ group and combination group $(\mathrm{p}=0.000)$, ketorolac group and combination group $(\mathrm{p}=0.000)$, and simvastatin group and combination group $(\mathrm{p}=0.002)$. Conclusion: the PAI-1 in peritoneal fluid was lower significantly in combination group, compared to the single administration of the drug group and control group.

Keywords: fibrinolysis, plasminogen activator inhibitor-1, adhesion, vitamin E, ketorolac, simvastatin.

\section{PENDAHULUAN}

Adhesi peritoneal didefinisikan sebagai adanya fibrous band yang abnormal antara organ atau jaringan atau keduanya di dalam kavum abdomen yang secara normal terpisah. Adhesi bisa didapat atau kongenital, namun yang paling banyak adalah didapat akibat adanya trauma pada peritoneum terutama oleh karena pembedahan pada abdomen dan pelvis. ${ }^{1,2}$ Adhesi setelah operasi terjadi sekitar $90 \%$ dari seluruh pasien yang dilakukan pembedahan pada abdomen dan menimbulkan setidaknya 1 rawat inap dari 3 pasien yang dilakukan pembedahan dalam 10 tahun. $^{3}$ Kejadian adhesi pada bayi dengan omfalokel dengan disertai obstruksi usus halus berkisar $12 \%$ dan $27 \%$ pada gastroskisis dalam 1 tahun pertama. Insidensinya terus meningkat setelah 10 tahun yaitu menjadi $15 \%$ pada omfalokel dan $37 \%$ pada gastroskisis. ${ }^{4}$ Penelitian oleh Eeson dkk, $84 \%$ pasien anak-anak dirawat inap dengan diagnosis obstruksi usus halus oleh karena adhesi setelah operasi memerlukan tindakan laparotomi. ${ }^{5}$ Kusumowidagdo dkk, meneliti bahwa dari 17 pasien yang dirawat di rumah sakit Dr. Hasan Sadikin pada tahun 2006 sampai tahun 2011 dengan diagnosis adhesi usus halus setelah operasi pada pasien pediatri, 11 pasien $(64,7 \%)$ memerlukan tindakan operatif. ${ }^{6}$
Ketertarikan terhadap mekanisme terjadinya adhesi setelah operasi menimbulkan upaya-upaya untuk menelitinya. Saat ini terdapat produk antiadhesi modern yang digunakan pada pasien dewasa dan memberikan hasil yang menjanjikan, mungkin dapat berperan pada operasi laparotomi neonatus yang memiliki risiko terjadinya morbiditas yang lebih tinggi akibat terbentuknya adhesi. ${ }^{4}$ Kunci dari upaya pencegahan terjadinya adhesi setelah operasi adalah inhibisi secara selektif baik satu atau lebih terhadap faktor yang dibutuhkan untuk terjadinya adhesi. ${ }^{1}$ Fibrinolisis merupakan kunci dalam memahami patogenesis dari adhesi, fibrinolisis berperan dalam proses adhesi adalah memecah gumpalan fibrin yang terbentuk selama proses penyembuhan. Plasminogen akan dirubah menjadi plasmin oleh tissue plasminogen activator (tPA) dan urokinase-like plaminogen activator (uPA). Peranan utama dari plasmin adalah degradasi fibrin, sedangkan yang menghalangi proses ini terjadi adalah plasminogen activator inhibitor-1 (PAI-1) dan plasminogen activator inhibitor-2 (PAI-2). PAI-1 lebih berperan dominan dalam menghambat aktifitas tPA dan uPA. Bila PAI meningkat maka proses fibrinolisis terganggu sehingga terbentuk adhesi. $^{7-9}$

Berbagai upaya dilakukan untuk mencegah terjadinya adhesi baik dengan 
mengurangi kerusakan peritoneum, mencegah terbentuknya fibrin, mencegah reaksi inflamasi, merangsang fibrinolysis, dan mencegah organisasi fibrin, serta separasi permukaan yang rusak. ${ }^{1}$ Penelitian tentang upaya pencegahan adhesi saat ini lebih banyak difokuskan untuk pengobatan tunggal, baik yang mencegah dari sisi anti inflamasi, fibrinolitik, dan barier antiadhesi. Penelitian yang mengkombinasikan ketiga obat tersebut untuk menurunkan kadar PAI-1 cairan peritoneum melalui tiga mekanisme tersebut belum pernah dilakukan sebelumnya.

Vitamin E merupakan vitamin yang paling sering diteliti dalam mencegah adhesi. Secara invitro vitamin E memiliki efek sebagai antioksidan, antiinflamasi, antikoagulan, efek antifibroblastik, mengurangi produksi kolagen, dan dianggap efektif dalam mengurangi kejadian adhesi. ${ }^{8,10,11}$ Menurut Corales dkk, pemberian vitamin $\mathrm{E}$ intraperitoneal memiliki efektifitas yang sama dengan membran carboxymethyl cellulose sebagai bioreabsorbable barier dalam mencegah adhesi. ${ }^{12}$ Penelitian lain oleh Makaraska dkk, menyimpulkan bahwa pemberian vitamin $\mathrm{E}$ intraperitoneal menurunkan intensitas dan luasnya adhesi peritoneum baik dilihat secara makroskopis maupun mikroskopis. ${ }^{13}$ Pemberian vitamin E intraperitoneal sebagai barrier mekanik efektif dalam menekan terjadinya adhesi dibandingkan diberikan secara intramuskular. ${ }^{8}$ Hal ini juga dikatakan oleh Portilla dkk bahwa dengan pemberian vitamin E yang dilarutkan dalam olive oil yang diberikan secara intraperitoneal dapat menurunkan terbentuknya adhesi sampai $80 \% .^{14}$

Simvastatin merupakan inhibitor dari 3hydroxy 3-methylglutaryl-coenzyme A (HMG-CoA) reduktase, awalnya didesain sebagai obat untuk menurunkan kolesterol darah, tetapi sekarang diketahui efek simvastatin yang tidak berhubungan dengan kapasitasnya dalam menurunkan lipid. Simvastatin memiliki efek yang kuat dalam meningkatkan sintesis tPA dan menurunkan PAI-1.15,16 Simvastatin dikatakan obat yang efektif untuk memperkuat kapasitas fibrinolitik sel mesotel. ${ }^{15}$

Ketorolak merupakan salah satu obat antiinflamasi non-steroid yang memiliki efek antiprostaglandin yang berperan menghambat efek adhesiogenik dari prostaglandin sehingga berperan sebagai antiadhesi. ${ }^{17} \mathrm{Hal}$ ini sesuai dengan apa yang disampaikan oleh Holschneider dkk, bahwa pemberian ketorolak akan menurunkan kejadian adhesi dan apabila terbentuk adhesi, maka adhesi yang terbentuk lebih tipis. $^{18}$

Vitamin E, simvastatin, dan ketorolak masing-masing bekerja melalui mekanisme yang berbeda dalam mencegah terjadinya adhesi. Penggunaan kombinasi ketiga obat tersebut akan menurunkan kadar PAI-1 cairan peritoneum sehingga proses fibrinolisis meningkat dan kejadian adhesi berkurang. Berdasarkan pemikiran tersebut ingin diketahui efek kombinasi dari vitamin E topikal sebagai bioreabsorbable barier, simvastatin oral sebagai obat fibrinolitik dan keterolac intramuskular sebagai antiinflamasi terhadap kadar PAI-1 cairan peritoneum yang berperan dalam mencegah proses fibrinolisis pada kejadian adhesi.

\section{METODE}

Penelitian ini menggunakan desain penelitian eksperimental dengan menggunakan binatang percobaan sebagai objek penelitian. Percobaan dilakukan dengan randomized control trial. Pada penelitian ini digunakan tikus Wistar karena struktur jaringan ususnya mirip dengan manusia. Selain itu tikus Wistar 
adalah hewan yang kooperatif (tidak menggigit bila dipegang). Kelompok penelitian dibagi menjadi 5 yaitu kelompok kontrol (K), perlakuan 1 (P1), perlakuan 2 (P2), perlakuan 3 (P3), dan perlakuan (P4). Kelompok kontrol, tikus Wistar yang dibuat adhesi intraperitoneum dengan cara abrasi ileum. Kelompok perlakuan 1, tikus Wistar yang dibuat adhesi intraperitoneum dengan cara abrasi ileum dan diberi vitamin E dalam olive oil topikal intraperitoneum. Kelompok perlakuan 2, tikus Wistar yang dibuat adhesi intraperitoneum dengan cara abrasi ileum dan diberi ketorolak trometamine intramuskular (tiap 6 jam selama 72 jam setelah operasi). Kelompok perlakuan 3, tikus Wistar yang dibuat adhesi intraperitoneum dengan cara abrasi ileum dan diberi simvastatin peroral (diberikan tiap hari). Kelompok perlakuan 4, tikus Wistar yang dibuat adhesi intraperitoneum dengan cara abrasi ileum dan diberi kombinasi antara vitamin $\mathrm{E}$ topikal intraperitoneum, ketorolak trometamine intramuskular (tiap 6 jam selama 72 jam setelah operasi) dan simvastatin peroral tiap hari. Besar sampel ditentukan dengan rumus Federer (26), dan didapatkan didapatkan besar sampel minimal untuk tiap perlakuan minimal 6 tikus Wistar. Masing-masing kelompok dilakukan pengambilan sampel dari cairan peritoneum tikus Wistar, untuk selanjutnya dinilai kadar PAI 1 dengan pemeriksaan ELISA.

Analisis statistik untuk mengetahui beda kadar PAI 1 cairan peritoneum antar kelompok kontrol, perlakuan tunggal dengan perlakuan kombinasi. Uji normalitas data dilakukan dengan uji Shapiro Wilk. Bila distribusi data normal, maka analisis data dilakukan dengan menggunakan one-way ANOVA.

\section{HASIL}

Penelitian ini menilai perbedaan kadar PAI-1 cairan peritoneum tikus Wistar antara yang diberi obat tunggal vitamin $\mathrm{E}$ topikal atau ketorolak intramuskular atau simvastatin oral dengan yang diberi obat kombinasi ketiganya pada tikus Wistar yang dilakukan abrasi ileum pada hari ke-7 setelah abrasi ileum yang dilakukan di Laboratorium Farmakologi FK UNPAD dan Laboratorium Patologi Klinik Rumah Sakit Hasan Sadikin / FK UNPAD pada bulan April 2014 (tabel 1).

Tabel 1. Nilai rerata kadar PAI-1 cairan peritoneum tikus Wistar pada tiap kelompok

\begin{tabular}{lccc}
\hline Kelompok & n & $\begin{array}{c}\text { Rerata kadar } \\
\text { PAI-1 } \\
(\mathbf{n g} / \mathbf{m l})\end{array}$ & $\begin{array}{c}\text { Standar } \\
\text { Deviasi }\end{array}$ \\
\hline Kontrol & 6 & 0,0757 & 0,0368 \\
Vitamin E & 6 & 0,0352 & 0,0032 \\
Ketorolak & 6 & 0,0343 & 0,0034 \\
Simvastatin & 6 & 0,0295 & 0,0059 \\
Vitamin E + & 6 & 0,0095 & 0,0021 \\
$\quad$ Ketorolak + & & & \\
$\quad$ Simvastatin & & & \\
\hline
\end{tabular}

Pada penelitian ini, data sampel adalah numerik, lebih dari 2 kelompok dan tidak berpasangan, sehingga hipotesa diuji dengan menggunakan one-way ANOVA. Pada penelitian ini dilakukan uji normalitas dengan Shapiro-Wilk didapatkan data terdistribusi normal. Namun setelah dilakukan uji varians didapatkan varians data tidak sama $(\mathrm{p}=0,001)$ sehingga untuk analisis post hoc dipilih Dunett's T3 didapatkan hasilnya seperti pada tabel 2.

Dari tabel 2 dapat dilihat adanya perbedaan bermakna antara kelompok kontrol dibandingkan dengan kelompok yang mendapat kombinasi ketiga obat $(\mathrm{p}=0,046)$, kelompok yang mendapat vitamin $\mathrm{E}$ topikal dibandingkan dengan kelompok yang mendapat kombinasi ketiga 
obat $(\mathrm{p}<0,01)$, kelompok yang mendapat ketorolak intramuskular dibandingkan dengan kelompok yang mendapat kombinasi ketiga obat $(\mathrm{p}<0,01)$, dan kelompok yang mendapatkan simvastatin oral dibandingkan dengan kelompok yang mendapat kombinasi ketiga obat tersebut $(\mathrm{p}=0,002)$.

Tabel 2. Uji beda antar kelompok perlakuan dengan uji post hoc Dunett's T3 kadar PAI-1 cairan peritoneum

\begin{tabular}{lc}
\hline Kelompok & $\begin{array}{c}\text { Vitamin E + Ketorolak } \\
\text { + Simvastatin (P4) }\end{array}$ \\
\hline Kontrol (K) & $\mathrm{p}=0,046$ \\
Vitamin E (P1) & $\mathrm{p}<0,01$ \\
Ketorolak (P2) & $\mathrm{p}<0,01$ \\
Simvastatin & $\mathrm{p}=0,002$ \\
(P3) & \\
\hline
\end{tabular}

\section{DISKUSI}

Penelitian ini merupakan penelitian eksperimental dengan menggunakan binatang percobaan sebagai objek penelitian. Percobaan dilakukan dengan randomized control trial. Kelompok penelitian dibagi menjadi 5 yaitu kelompok kontrol (K), Perlakuan 1 (P1), Perlakuan 2 (P2), Perlakuan 3 (P3) dan Perlakuan 4 (P4) dengan masing-masing kelompok terdiri dari 6 tikus Wistar. Dilakukan analisis statistik untuk mengetahui beda kadar PAI 1 cairan peritoneum antar kelompok kontrol, perlakuan tunggal dengan perlakuan kombinasi. Uji normalitas data dilakukan dengan uji shapiro wilk dan didapatkan sebaran data normal. Dinilai juga varians antar kelompok data, didapatkan varians data berbeda sehingga uji post hoc yang digunakan pada one-way ANOVA adalah Dunett's T3. Didapatkan rerata kadar PAI-1 cairan peritoneum tikus Wistar pada kelompok kontrol 0,0757 $\mathrm{ng} / \mathrm{ml}$, kelompok yang diberi obat tunggal vitamin E topikal 0,0352 ng/ml, kelompok yang diberi ketorolak intramuskular 0,0343 ng/ml, kelompok yang diberi simvastatin oral $0,0295 \mathrm{ng} / \mathrm{ml}$, dan kelompok yang diberi obat kombinasi ketiganya 0,0095 $\mathrm{ng} / \mathrm{ml}$ seperti yang tampak pada tabel 1 .

Dari hasil penelitian ini didapatkan rerata kadar PAI-1 cairan peritoneum tikus Wistar lebih rendah pada kelompok yang diberi obat tunggal baik yang diberi vitamin E topikal $(0,0352 \mathrm{ng} / \mathrm{ml})$ atau ketorolak intramuskular $(0,0343 \mathrm{ng} / \mathrm{ml})$ atau simvastatin oral $(0,0295 \mathrm{ng} / \mathrm{ml})$ dan paling rendah pada kelompok yang diberi kombinasi ketiga obat tersebut $(0,0095$ $\mathrm{ng} / \mathrm{ml}$ ) dibandingkan dengan kelompok kontrol $(0,0757 \mathrm{ng} / \mathrm{ml})$. Dilihat perbedaan rerata kadar PAI-1 cairan peritoneum antara kelompok kontrol dengan kelompok perlakuan yang diberi kombinasi ketiga obat $(\mathrm{p}=0,046)$, antara kelompok yang diberi vitamin $\mathrm{E}$ topikal dengan kombinasi $(\mathrm{p}<0,01)$, antara kelompok yang diberi ketorolak intramuskular dengan kombinasi $(\mathrm{p}<0,01)$, antara kelompok yang diberi simvastatin dengan kombinasi $(\mathrm{p}=0,002)$. Jadi pemberian kombinasi ketiga obat terbukti menurunkan kadar PAI-1 cairan peritoneum baik dibandingkan dengan pemberian obat tunggal maupun tidak diberi obat.

Jika dilihat rerata kadar PAI-1 cairan peritoneum diantara kelompok yang mendapatkan obat tunggal, penurunan kadar PAI-1 paling rendah pada kelompok yang mendapatkan simvastatin oral, hal ini disebabkan oleh karena simvastatin oral bekerja langsung dengan jalan menurunkan kadar PAI-1 dan meningkatkan level dari tPA sehingga proses fibrinolitik meningkat. ${ }^{19}$ Simvastatin merupakan obat golongan statin yang menurunkan level dari kolesterol LDL (low density lipoprotein) dan sitokin proinflamasi. Pemberian terapi simvastatin telah menunjukkan bahwa simvastatin bekerja pada ketiga marker yaitu PAI-1, sCD40L dan sP-selectin yang terbukti memiliki peran penting dalam 
proses fibrinolisis dan koagulasi. ${ }^{20}$ Penelitian oleh Aarons dkk pada tikus menunjukkan bahwa obat golongan statin efektif dalam menurunkan terbentuknya adhesi dengan merangsang profibrinolitik pada peritoneum tanpa menimbulkan perdarahan pada peritoneum ataupun mengganggu penyembuhan anastomosis usus. $^{21}$ penelitian oleh Heslinger dkk menunjukkan bahwa simvastatin secara kuat merangsang kapasitas fibrinolitik dari sel mesotel. Aksi dari simvastatin pada proses fibrinolitik peritoneum mungkin merupakan mekanisme baru dalam menghilangkan deposisi awal dari fibrin pada kavum peritoneum pada pasien dengan peritoneal dialisa, sehingga dapat mencegah penebalan peritoneum dan terbentuknya adhesi. ${ }^{15}$

Berbeda halnya dengan pemberian ketorolak intramuskular dan vitamin $\mathrm{E}$ topikal yang bekerja melalui mekanisme antiinflamasi untuk menurunkan kadar PAI-1. Pada kasus trauma peritoneum akan terjadi respon inflamasi yang akan merangsang pelepasan sitokin terutama TGF- $\beta 1$ dan sitokin lainnya seperti TNF- $\alpha$, IL-1, dan IL-6 yang akan merangsang pelepasan PAI-1 sehinggga mencegah terjadinya proses fibrinolisis. ${ }^{22}$ Ketorolak merupakan antiinflamasi non steroid yang tersedia dalam bentuk intravena, intramuskular, dan formulasi oral yang memiliki efek menurunkan level sitokin yaitu TNF- $\alpha$, IL-6, dan IL-1 $\beta$ sehingga menghambat ekspresi molekul inflamasi. ${ }^{23}$ Oleh karena perannya menekan proses inflamasi sehingga terjadi hambatan pelepasan PAI-1, sehingga terjadi proses fibrinolisis. $^{24}$

Vitamin E berperan menurunkan proses inflamasi yang dirangsang setelah terjadi trauma peritoneum, oleh karena menghambat cyclooxygenase-2 (COX-2) dan mengkonversi secara endogen asam arakidonat menjadi $\mathrm{PGF}_{2}$ dan
$\mathrm{PGF}_{2 \alpha . .}$ Perannya sebagai antioksidan bahkan lebih menarik, vitamin $\mathrm{E}$ akan menghambat terjadinya oksidasi pada fase awal saat dilepaskannya radikal bebas, yang mana proses ini berperan penting dalam proses inflamasi dan terbentuknya adhesi. Sebagai tambahan vitamin E memiliki efek sebagai antifibroblas, juga menghambat TGF-beta, yang merupakan sitokin perangsang fibrosis dan menurunkan produksi kolagen. Pemberian vitamin E secara oral hanya dapat diabsorbsi $20-60 \%$ saja, sedangkan apabila diberikan secara intraperitoneal dapat menurunkan terbentuknya adhesi sampai $80 \% .{ }^{14}$ Sehingga perannya sebagai antioksidan dan antiiflamasi akan menurunkan pelepasan PAI sehingga mencegah proses fibrosis dan meningkatkan fibrinolisis. ${ }^{24}$ Vitamin E juga memiliki peran sebagai bioreabsorbable barrier dalam mencegah adhesi. ${ }^{12}$

Penulis menyadari adanya keterbatasan dalam penelitian ini. Penelitian ini merupakan penelitian eksperimental pada hewan coba sehingga efek pemberian ketiga obat yaitu vitamin E topikal, simvastatin oral, dan ketorolak intramuskular terhadap penurunan kadar PAI cairan peritoneum tikus Wistar yang akan mengurangi terjadinya adhesi intraperitoneal belum tentu menghasilkan efek yang sama terhadap manusia terutama pada pasien bedah anak dengan pembedahan abdomen yang memiliki risiko terjadinya adhesi.

\section{SIMPULAN}

Kadar PAI-1 cairan peritoneum pada tikus Wistar yang dilakukan abrasi ileum dan diberi obat kombinasi vitamin $\mathrm{E}$ dalam olive oil topikal intraperitoneum, ketorolak intramuskular, dan simvastatin oral lebih rendah secara bermakna dibandingkan jika hanya diberi vitamin $\mathrm{E}$ dalam olive oil 
topikal intraperitoneum. Begitu pula dengan jika hanya diberi ketorolak intramuskular. Lebih rendah secara bermakna juga dibandingkan dengan jika hanya diberi simvastatin oral, serta lebih rendah secara bermakna jika hanya dibandingkan dengan jika tanpa pemberian obat.

\section{DAFTAR PUSTAKA}

1. Attard J-AP, MacLean AR. Adhesive Small Bowel Obstruction: Epidemiology, Biology and Prevention. Can J Surg Canada. 2007;50:290-300.

2. Irkorucu O, Ferahköșe Z, Memiş L, et al. Reduction of Postsurgical Adhesions in a Rat Model: a Comparative Study. Clinics. 2009;64:143-8.

3. Schreinemacher MHF, ten Broek RP, Bakkum EA, et al. Adhesion Awareness: A National Survey of Surgeons. World J Surg. 2010;34:2805-12.

4. van Eijck FC, Wijnen RM, van Goor $H$. The Incidence and Morbidity of Adhesions After Treatment of Neonates With Gastroschisis and Omphalocele: a 30-Year Review. $J$ Pediatr Surg. 2008;43:479-83.

5. Eeson GA, Wales P, Murphy JJ. Adhesive Small Bowel Obstruction in Children. $J$ Pediatr Surg. 2010:45:969-74.

6. Kusumowidagdo F, Kusmayadi DD, Nawas BA, et al. Adhesi Usus Halus Pasca Operasi pada Pasien Pediatrik: Faktor yang Mempengaruhi Kegagalan Manajemen Non-Operatif. Pertemuan Ilmiah Berkala XX Persatuan Bedah Anak Indonesia (PERBANI). Banjarmasin 2-4 Marert; 2012.
7. Cesarman-Maus G, Hajar KA. Molecular Mechanisms of Fibrinolysis. British Journal of Haematology. 2005;129:307-21.

8. Arung $\mathrm{W}$, Meurisse $\mathrm{M}$, Detry $\mathrm{O}$. Pathophysiology and Prevention of Postoperative Peritoneal Adhesions. World J Gastroenterol. 2011;17:454553.

9. Cheong YC, Laird SM, Li TC, et al. Peritoneal Healing and Adhesion Formation/Reformation. Human Reproduction Update. 2001;7:556-66.

10. Tulandi T, Al-Shahrani A. Adhesion Prevention in Gynecologic Surgery. Current Opinion in Obstetrics and Gynecology. 2005; 17:395-8.

11. Durmus AS, Yildiz H, Yaman I, et al. Efficacy of Vitamin E and Selenium for the Prevention of Intra-abdominal Adhesions in Rats: Uterine Horn Models. Clinics. 2011;66:1247-51.

12. Corrales F, Corrales M, Schirmer CC. Preventing Intraperitoneal Adhesions with Vitamin E and Sodium Hyaluronate/Carboxymethylcellulose: A Comparative Study in Rats. Acta Cir Bras. 2008;23:36-41.

13. Makarska J, Sosada K, Stępien T, et al. Influence of Vitamin $\mathrm{E}$ Given Intraperitoneally to Prevent Peritoneal Adhesions in Rats. Polish Journal of Surgery. 2010;82:547-52.

14. Haslinger B, Goedde FM, Toet HK, et al. Simvastatin Increases Fibrinolytic Activity in Human Peritoneal Mesothelial Cells Independent of Cholesterol Lowering. Kidney International. 2002;62:1611-9.

15. van der Wal JBC, Jeekel J. The Use of Statins in Postoperative Adhesion Prevention. Ann Surg. 2007;245:18586. 
16. Kamel RM. Prevention of Postoperative Peritoneal Adhesions. European Journal of Obstetrics \& Gynecology and Reproductive Biology. 2010;150:111-8.

17. Molinas CR, Binda MM, Manavella GD, et al. Adhesion Formation after Laparoscopic Surgery: What Do We Know about The Role of The Peritoneal Environnment? Facts Views Vis Obgyn. 2010;2:149-160.

18. Al-Musawi D, Thompson JN. Adhesion Prevention: State of The Art. Gynaecological Endoscopy. 2001;10:123-130.

19. Gharibzadeh S, Hoseini SS. Does TGF beta Suppressing Effect of Simvastatin Lead to Protection Againts Surgical Adhesion Band Formation? Iranian Journal of Medical Hypotheses and Ideas. 2008;2:1-4.

20. Wang L, Rockwood J, Zak D, et al. Simvastatin Reduces Circulating Plasminogen Activator Inhibitor 1 Activity in Volunteers with the Metabolic Syndrome. Metab Syndr Relat Disord. 2008;6:149-52.

21. Cheung ME. "A Swine Model for the Quantification of Pelvic and the Encapsulation of Ketorolac Tromethamine for the Prevention of Adhesion Formation" (dissertation). Ohio: University of Akron; 2010.

22. Atta HM. Prevention of Peritoneal Adhesion: a Promising Role for Gene Therapy. World J Gastroenterol. 2011;17:5049-58.

23. Cheung JP, Tsang HH, Cheung JJ, et al. Adjuvant Therapy for the Reduction of Postoperative Intra-abdominal Adhesion Formation. Asian J Surg. 2009;32:180-6.

24. El-Daharawy M, Helal I. Human Amniotic and VitaminE/Selenium for
Control of Postoperative Adhesion in Dogs. Jpn J Vet Res. 2011;59:165-71. 